\title{
Lysosomal function in macromolecular homeostasis and bioenergetics in Parkinson's disease
}

\author{
Lonnie Schneider, Jianhua Zhang*
}

\begin{abstract}
The pathological changes occurring in Parkinson's and several other neurodegenerative diseases are complex and poorly understood, but all clearly involve protein aggregation. Also frequently appearing in neurodegeneration is mitochondrial dysfunction which may precede, coincide or follow protein aggregation. These observations led to the concept that protein aggregation and mitochondrial dysfunction either arise from the same etiological factors or are interactive. Understanding the mechanisms and regulation of processes that lead to protein aggregation or mitochondrial dysfunction may therefore contribute to the design of better therapeutics. Clearance of protein aggregates and dysfunctional organelles is dependent on macroautophagy which is the process through which aged or damaged proteins and organelles are first degraded by the lysosome and then recycled. The macroautophagy-lysosomal pathway is essential for maintaining protein and energy homeostasis. Not surprisingly, failure of the lysosomal system has been implicated in diseases that have features of protein aggregation and mitochondrial dysfunction. This review summarizes 3 major topics: 1) the current understanding of Parkinson's disease pathogenesis in terms of accumulation of damaged proteins and reduction of cellular bioenergetics; 2) evolving insights into lysosomal function and biogenesis and the accumulating evidence that lysosomal dysfunction may cause or exacerbate Parkinsonian pathology and finally 3 ) the possibility that enhancing lysosomal function may provide a disease modifying therapy.
\end{abstract}

\section{Introduction}

A long-term objective in the study of neurodegenerative diseases is to identify the mechanisms of how cells cope with damage to protein and organelles. Ultimately, this should aid in the design of novel and effective treatment strategies. The failure to clear effectively aged and damaged proteins and organelles is implicated in aging and several neurodegenerative diseases. The lysosome is the high capacity organelle responsible for the normal process of protein and organellar degradation [1-4]. The appearance of aggregated proteins in the cells associated with neurodegenerative diseases is common and suggests a dysfunction in the normal protein degradation pathways including the lysosome $[5,6]$.

$\alpha$-synuclein accumulation is commonly associated with Parkinson's disease. Mutations in this protein or

\footnotetext{
* Correspondence: zhanja@uab.edu

* Correspondence: zhanja@uab.edu
Department of Pathology, University of Alabama at Birmingham, Birmingham, AL35294, USA
}

(C) 2010 Schneider and Zhang; licensee BioMed Central Ltd. This is an Open Access article distributed under the terms of the Creative

gene amplification cause a small subset of Parkinson's disease cases, with Lewy body formation, neurodegeneration and often an associated dementia $[7,8]$. Further, in many sporadic Parkinson's patients who do not carry mutations or upregulation of expression, $\alpha$-synuclein aggregation is also widespread $[9,10]$, implicating a dysfunction of its degradation in neurons. Further, supporting a central role of $\alpha$-synuclein in disease pathogenesis, its reduction in experimental models is neuroprotective [11-15]. These observations suggest the therapeutic strategy of enhancing lysosomal function in treatment of Parkinson's and other neurodegenerative diseases. This review will summarize our current understanding of Parkinson's disease with respect to $\alpha$-synuclein aggregation and mitochondrial dysfunction, examine how lysosomal function is regulated and review the evidence supporting the hypothesis that enhancing lysosomal function is neuroprotective. 


\section{Parkinson's Disease}

Parkinson's disease is the second most common neurodegenerative disease and the most common movement disorder, affecting $1 \%$ of the population above the age of 60. Its clinical features include tremor, muscle rigidity, bradykinesia and postural instability. These debilitating symptoms are attributed primarily to degeneration of substantia nigra dopaminergic neurons. Parkinson's disease is associated with both genetic and non-genetic contributing factors, with aging as the most prominent risk factor. Both protein aggregation and mitochondrial dysfunction feature prominently in Parkinson's disease [16]. These two disease features and their inter-connection are summarized below.

\section{1a. $\alpha$-synuclein aggregation in Parkinson's disease}

Lewy body formation with $\alpha$-synuclein accumulation is a prototypical pathological feature in Parkinson's and other Lewy body diseases. $\alpha$-synuclein is a 140 amino acid protein which has a propensity to associate with membranes $[17,18]$. Its interaction with membranes of different composition can change both the membrane structure and the tendency of $\alpha$-synuclein to form fibrils [19-25]. Not surprisingly, $\alpha$-synuclein is enriched at synaptic termini in neurons [26,27], where it is thought to modulate synaptic vesicle release and neuronal fatty acid composition [26-28]. $\alpha$-synuclein association with the synapse may be regulated by synaptic activities [29] and is increased during learning [30].

Patients with $\alpha$-synuclein A53T, A30P, or E46K mutations develop typical Parkinson's disease, with Lewy body formation, neurodegeneration and often an associated dementia $[7,8]$. These mutations in $\alpha$-synuclein alter its dynamic interactions with membranes [31]. Triplication of the wildtype $\alpha$-synuclein gene has also been shown to cause Parkinson's disease [8], lending to the idea that increased levels of $\alpha$-synuclein protein may play a crucial role in the development of idiopathic Parkinson's disease. Further support for this notion is the finding that $\alpha$-synuclein overexpression leads to its aggregation and/or neurotoxicity in animal models [32-34].

The intracellular concentrations of $\alpha$-synuclein protein are regulated at mRNA transcription, protein synthesis and targeting, or protein degradation levels. Blockade of $\alpha$-synuclein production by ribozyme or siRNA could reduce $\alpha$-synuclein production [11-15], but may not be effective to clear already formed toxic species. Recent studies on $\alpha$-synuclein transcription regulation may provide clues on how to turn off $\alpha$-synuclein production [35-37]. Conditionally turning off $\alpha$-synuclein production after inclusion body formation in a mouse model attenuated progression but did not reverse $\alpha$-synuclein over-production-induced deficits [38]. One therapeutic strategy is immunization with antibodies [39] to reduce $\alpha$-synuclein proteins, but this is limited by the requirement for exposure of specific epitopes on the protein and access across the blood-brain barrier.

Furthermore, in $>90 \%$ of Parkinson's disease cases, and almost all Dementia with Lewy bodies and Lewy body variants of Alzheimer's disease cases, the $\alpha$-synuclein gene is not mutated nor is $\alpha$-synuclein mRNA overexpressed $[40,41]$. Nonetheless, $\alpha$-synuclein aggregates are invariably present as a main component of the Lewy body and levels of this protein are increased in both Triton X-100 soluble and insoluble fractions of whole cell extracts $[9,10]$. These observations suggest that defective $\alpha$-synuclein protein degradation is a more important pathogenic factor than $\alpha$-synuclein overproduction in these cases. In addition to accumulation of protein aggregates, mitochondrial deficits have also been observed to occur in Parkinson's and other neurodegenerative diseases.

\section{1b. Mitochondrial defects in Parkinson's disease}

Parkinson's disease brains exhibit a reduction in mitochondrial complex I activity, which is both the rate-limiting step for mitochondrial respiratory chain activity, and an important site for generation of reactive oxygen species $[42,43]$. Reduction of complex I activity may lead to accumulation of reactive oxygen species, which can further induce mitochondrial permeability transition, ATP depletion, and damage of DNA, lipids and proteins. Similar mitochondrial defects are also seen in the Parkinson's disease patients' cortex, in addition to the substantia nigra, suggesting that the reduced mitochondrial activity is not solely due to the extensive (can be as high as $80 \%$ ) dopaminergic neuron loss in the substantia nigra [43-45]. Mitochondrial complex II, III and $\mathrm{V}$ proteins are also reduced in sporadic Parkinson's disease brains [46].

Somatic mtDNA mutations and mitochondrial dysfunction are increased with aging and have been found in Parkinson's and other neurodegenerative diseases $[45,47-50]$. In addition, recently studies have indicated that mitochondrial dynamics may be defective in Parkinson's disease, including abnormalities in axonal transport, mitochondrial fission and fusion. Axonal degeneration and associated mitochondrial defects occur in a number of neurodegenerative diseases [51-53], particularly because of the long distances the axons in affected neurons traverse. Neurodegeneration may be initiated in the axons or even the synapse, and subsequently extended to the cell body $[52,54]$.

Mitochondrial dysfunction may be induced by environmental toxins that could possibly contribute to Parkinson "like" diseases. For example, 1-methyl 4-phenyl 
1,2,3,6-tetrahydropyridine (MPTP) was originally discovered as a byproduct of illegal heroin production, and was shown to cause a Parkinsonian syndrome in drug users [55-58]. MPTP is the neurotoxin that crosses the blood-brain barrier in a matter of seconds, whereby it is rapidly converted to 1-methyl-4-phenylpyridinium (MPP + ) by endogenous monoamine oxidase $\mathrm{B}$. MPP+ is able to selectively enter dopaminergic neurons of the substantia nigra based on its size and charge facilitating entry through the dopamine transporter. Upon entering dopaminergic neurons, MPP+ accumulates in mitochondria where it binds to and inhibits complex I, causing ATP depletion, and increasing reactive oxygen species $[59,60]$. Pesticides rotenone and paraquat that directly and indirectly target to the mitochondria have also been implicated in animal models of Parkinsonism [59,61-64].

These data suggest that mitochondrial dysfunction is not simply an inconsequential phenotype associated with Parkinson's and other neurodegenerative diseases, but in fact can be an initiating factor for pathogenesis. In support of this idea, if mitochondria isolated from Parkinson's disease patients are transferred into mitochondria-depleted neuroblastoma cells, inclusion bodies are formed $[65,66]$. Decreased mitochondrial biogenesis in MitoPark mice, with deficient mitochondrial transcription factor (Tfam) in midbrain dopaminergic neurons, led to adult onset and progressive Parkinsonism, and associated intraneuronal inclusions [67]. Furthermore, genes identified in rare inherited forms of Parkinson's disease are involved in regulating mitochondrial function [68].

\section{1c. Relationship between $\alpha$-synuclein accumulation and mitochondrial dysfunction in Parkinson's disease and experimental models}

Both $\alpha$-synuclein aggregation and mitochondrial dysfunction feature prominently in Parkinson's disease [16]. Whether these two features are interactive has inspired interesting studies in Parkinson's disease brains and experimental models. $\alpha$-synuclein interacts with the mitochondrial inner membrane [69,70], and accumulates at greater levels in the mitochondria of substantia nigra and striatal neurons in human Parkinson's disease brains compared to normal brains [70]. In vitro, $\alpha$-synuclein is targeted to mitochondria via an $\mathrm{N}$-terminal cryptic sequence [70], and decreases complex I activity and the production of reactive oxygen species [70-72]. $\alpha$-synuclein can also bind to mitochondrial complex IV, and is a possible further mechanism leading to mitochondrial dysfunction [73].

Sub-chronic administration of mitochondrial toxin MPTP has been shown to transiently induce $\alpha$-synuclein accumulation, followed by extensive cell death, precluding further $\alpha$-synuclein accumulation [74].
Chronic administration of MPTP together with probenecid leads to the accumulation of Lewy body-like structures that are $\alpha$-synuclein positive [75-77]. Probenecid is a uricosuric agent that decreases renal excretion of MPTP, thereby sustaining a higher level of MPTP in the brain compared to MPTP alone without probenecid $[78,79]$. Furthermore, $\alpha$-synuclein knockout mice are resistant to MPTP-induced dopaminergic neuron death [11-14]. Reduction of $\alpha$-synuclein by siRNA or ribozyme approaches is neuroprotective in vitro and in mitochondrial neurotoxin-based animal models $[15,80]$. Transgenic mice overexpressing human $\alpha$-synuclein exhibit increased pathology in response to MPTP treatment $[72,81,82]$. These studies suggest that a lysosomal dysfunction that is presumably inadequate to remove accumulated $\alpha$-synuclein may mediate mitochondrial dysfunction-caused neurodegeneration. A better understanding of the underlying mechanisms is critical to our understanding of Parkinson's disease pathogenesis.

\section{Lysosomes and their role in neurodegenerative diseases}

Lysosomes are acidic intracellular compartments that provide inherent protein-, lipid-, nucleic acid-and pathogen-degrading activities for the cell. They receive their substrates from endocytosis, phagocytosis and autophagy, and are active participants in bulk degradation of metabolic waste products [1]. For a long time, lysosomal enzyme functions were considered as merely downstream events that passively degrade materials that are transported to the organelle. Accumulating evidence however, has indicated that lysosomal activities are rate-limiting, induced under stress, and the major force in clearance of damaged or aggregated proteins [2,5,6,83,84]. In addition, they may even be vital in coordinating intracellular signaling and metabolic activities. Here we will evaluate relevant information regarding lysosomal functions and biogenesis, pertinent to neurodegenerative diseases. We will review current knowledge regarding regulation of normal lysosomal activities, and then summarize the involvement of lysosomal dysfunction in Parkinson's disease.

\section{2a. Regulation of normal lysosomal activities}

Nearly 100 lysosomal proteins are involved in the structure and activities of the organelle [85]. Almost all of these lysosomal proteins are indispensable for normal physiology in mammals, i.e., almost all have unique and non-redundant roles in the lysosome [5]. Some of the lysosomal enzymes are regulated at the transcriptional level by growth factors [86]. To ensure their coordinated function, the expression of many of the lysosomal proteins is regulated by common mechanisms [87]. 
One recent landmark work by Sardiello et al has provided new insights into how expression of lysosomal proteins is regulated. Using a bioinformatics approach, a large proportion (68 out of 96 genes) of all lysosomal genes examined contain a palindromic 10 base pair sequence (GTCACGTGAC) in the promoter regions that is a consensus binding site for a basic helix-loophelix (bHLH) transcription factor EB (TFEB) [87]. Conversely, an unbiased microarray analyses have shown that the 291 genes upregulated by TFEB are enriched for lysosomal genes by a stringent conservative criteria. Additional non-lysosomal TFEB-regulated genes play important roles in transporting enzymes and substrates to the lysosome. With TFEB upregulation, the overall lysosomal volumes are also increased, as measured by lysosomal membrane markers as well as ultra-structural studies. Coordinated regulation of lysosomal and vesicle transport protein levels may serve to ensure maximum efficiency of the system in times of stress, as well as highlight the cooperative nature of the acid hydrolases during macromolecular degradation. Furthermore, TFEB genetic polymorphisms may contribute to alterations of its function and predisposition to neurodegenerative diseases via alterations of transcription of lysosomal proteins (Figure 1).

In addition to gene expression, lysosomal activities are also regulated when proteins are targeted to the organelle. To ensure proper targeting, multiple pathways select and deliver lysosomal proteins to their final destinations. Trafficking of the more than 50 known lysosomal acid hydrolases is largely dependent on a mannose6-phosphate receptor (M6Pr)-mediated mechanism, although processes independent of mannose-6-phosphate receptor also exist. The mannose-6-phosphate receptor $(\mathrm{M} 6 \mathrm{Pr})$-dependent pathway is the most common pathway for trafficking of the acid hydrolases in the lysosomal lumen. Typically, the lysosomal acid hydrolases are synthesized with an $\mathrm{N}$-terminal signal peptide that is recognized by the signal recognition particle. The signal recognition particle enables the proteins to be translocated into the endoplasmic reticulum (ER) where a signal peptidase removes the signal peptide $[88,89]$. The proteins are then glycosylated and further processed to ensure proper protein folding. Once proteins are properly folded and audited by the endoplasmic reticulum (ER) fidelity machinery, the proteins are transported to the Golgi where oligosaccharide chains are modified by addition of complex sugars. The addition of the mannose-6-phosphate (M6P) marker to the protein takes place through stepwise enzymatic reactions, and is later recognized by the mannose-6-phosphate receptor $(\mathrm{M} 6 \mathrm{Pr})$, on the trans-Golgi for export in clathrin-coated vesicles and fusion with early and late endosomes. The low $\mathrm{pH}$ of the endosomes initiates dissociation of the lysosomal hydrolase from the mannose-6-phosphate receptors ( $\mathrm{M} 6 \mathrm{Pr})$. The hydrolase is subsequently delivered to the lysosome and the mannose-6-phosphate receptors (M6Pr) are recycled back to the Golgi for another round of protein transport.

Adding the mannose-6-phosphate requires $\mathrm{N}$-acetylglucosamine phosphotransferase activity [90-92]. The mannose-6-phosphate receptors, $300 \mathrm{kDa}$ CI-M6Pr and $46 \mathrm{kDa} C D-M 6 P r$, are required for recognizing mannose-6-phosphate-containing lysosomal proteins [93]. With deficiencies of these genes, as in human mucolipidoses II (also called I-cell disease) patients, or in double knockout of both of these mannose-6phosphate receptors, a portion of the lysosomal proteins do reach the lysosome, indicating the existence of mannose-6-phosphate receptor-independent trafficking pathways. Lysosomal integral membrane protein-2 (LIMP-2) [94], and sortilin-like receptor 1 (SORL1) [95-98], a multi-ligand type-1 receptor with similarity to the yeast carboxypeptidase $\mathrm{Y}$ sorting receptor Vps10 protein, are examples of proteins involved in such mannose-6-phosphate receptor-independent pathways. Deficiencies of these targeting proteins are implicated in Gaucher disease $[99,100]$, myoclonus epilepsy [94,101] and Alzheimer's diseases [102].

The lysosome contains more than 50 acid hydrolases. They are responsible for breaking down the sugar, lipid, glycolipids, glycosaminoglycans, nucleic acids and proteins. These enzymes work together to contribute to the total catabolic function of the lysosome. In the endosomes and lysosomes, precursor hydrolases undergo further proteolytic cleavage to become fully active. The cleavage of proenzymes into active forms occurring within the greater lysosomal systems prevents premature activation of hydrolases outside of the lysosomes. Endogenous inhibitors of some of the hydrolases also exist to facilitate the compartmentalized activity of the lysosomal enzymes [103-106]. Intracellular metabolites may be upregulated in response to stress to modulate lysosomal enzyme activities [107]. Lysosomal membranes maintain the acidic $\mathrm{pH}$ within the lumen of the lysosome, and play a key role in importing proteins from the cytosol, contacting and fusing with other vesicles such as lateendosomes and autophagosomes [108-110], and exporting degradation products back to the cytosol [111-113]. Defects in lysosomal enzymes and membranes can cause neurodegenerative diseases [5,114-119] (Figure 1).

Lysosomes are dynamic organelles controlling protein and organelle homeostasis. Autophagy-lysosomal pathway-mediated proteolysis has been thought to be a bulk mechanism for protein turnover, serving as a common endpoint for multiple vesicle-based trafficking systems [120]. Proteins destined to be degraded in lysosomes can be delivered to these organelles by macroautophagy 


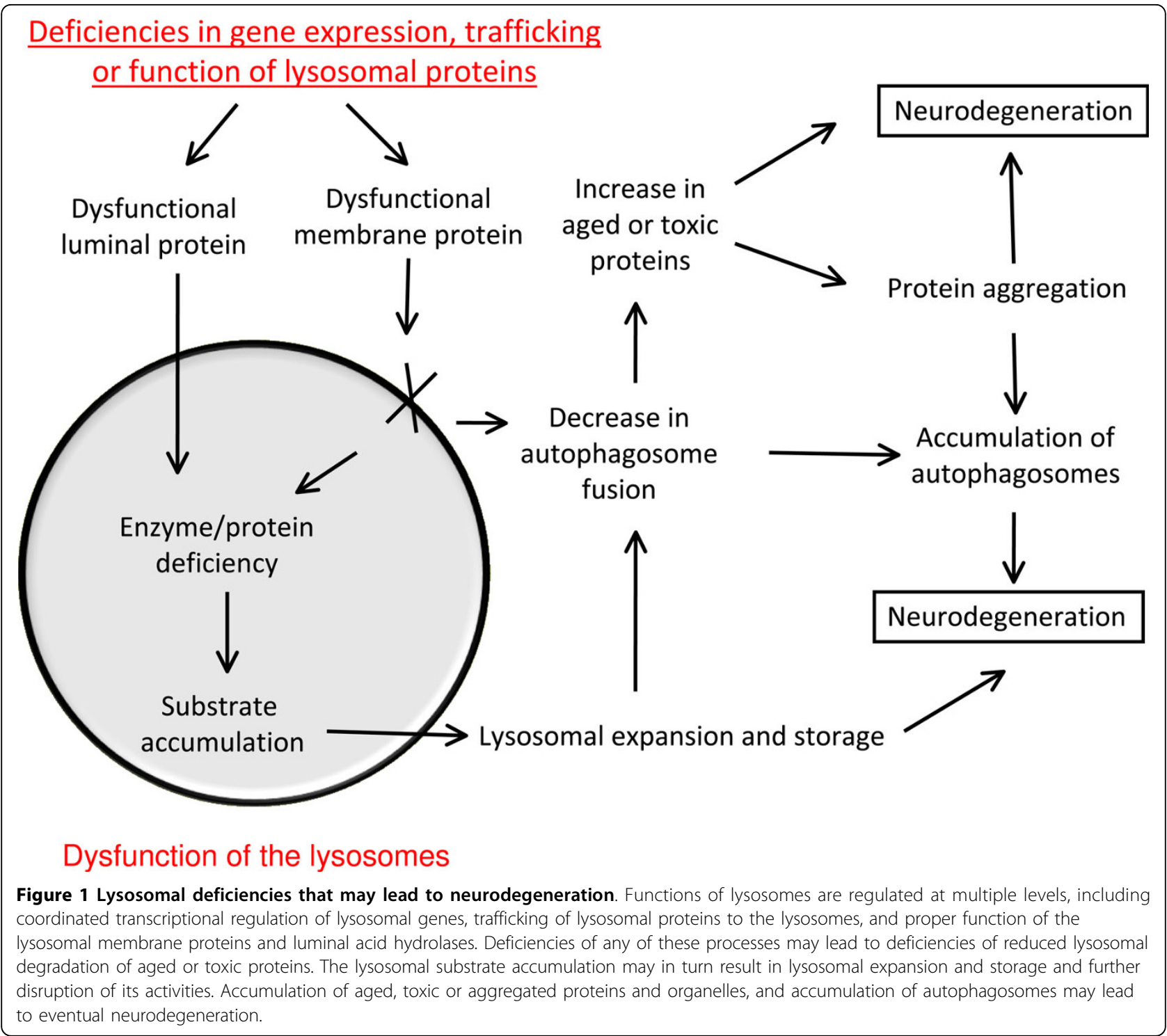

or by chaperone-mediated-autophagy. Macroautophagy delivers damaged proteins and organelles to the lysosome via autophagosomes. Autophagosome formation is initiated by de novo synthesis of double membrane vesicles or budding from endoplasmic reticulum, Golgi or mitochondria in the cytoplasm. These vesicles encircle aged or damaged proteins and organelles and deliver their cargos to lysosomes for degradation. Macroautophagy is induced by starvation to perform bulk recycling of proteins and organelles. In addition, nucleophagy [121], ribophagy [122], reticulophagy [123], mitophagy $[124,125]$, and pexophagy [126] regulate clearance of specific complexes and organelles. Chaperone-mediatedautophagy is initiated when chaperones bind to a consensus sequence in target proteins, and deliver them to the lysosomes via the chaperone-mediated-autophagy receptor, lysosomal-associated membrane protein $2 \mathrm{a}$ (LAMP-2a), which is a splice variant of LAMP-2 [127]. In the next section, we will discuss how lysosomal dysfunction contributes to neurodegenerative diseases.

\section{2b. Dysfunction of lysosomes in Parkinson's disease}

The lysosomal system has been proposed to be a genetic "hotspot" for neurodegenerative diseases [5,6]. And different types of lysosomal deficiency lead to distinct disease phenotypes. Malfunction of specific enzymes in the lysosome have been associated with Parkinson's disease. Deficiencies at multiple steps of the pathway contribute to susceptibilities to disease pathogenesis (Figure 1). Inhibition of lysosomal activities may also have indirect adverse effects on other proteolytic pathways [128]. We will review i) known genetic lysosomal deficiencies in 


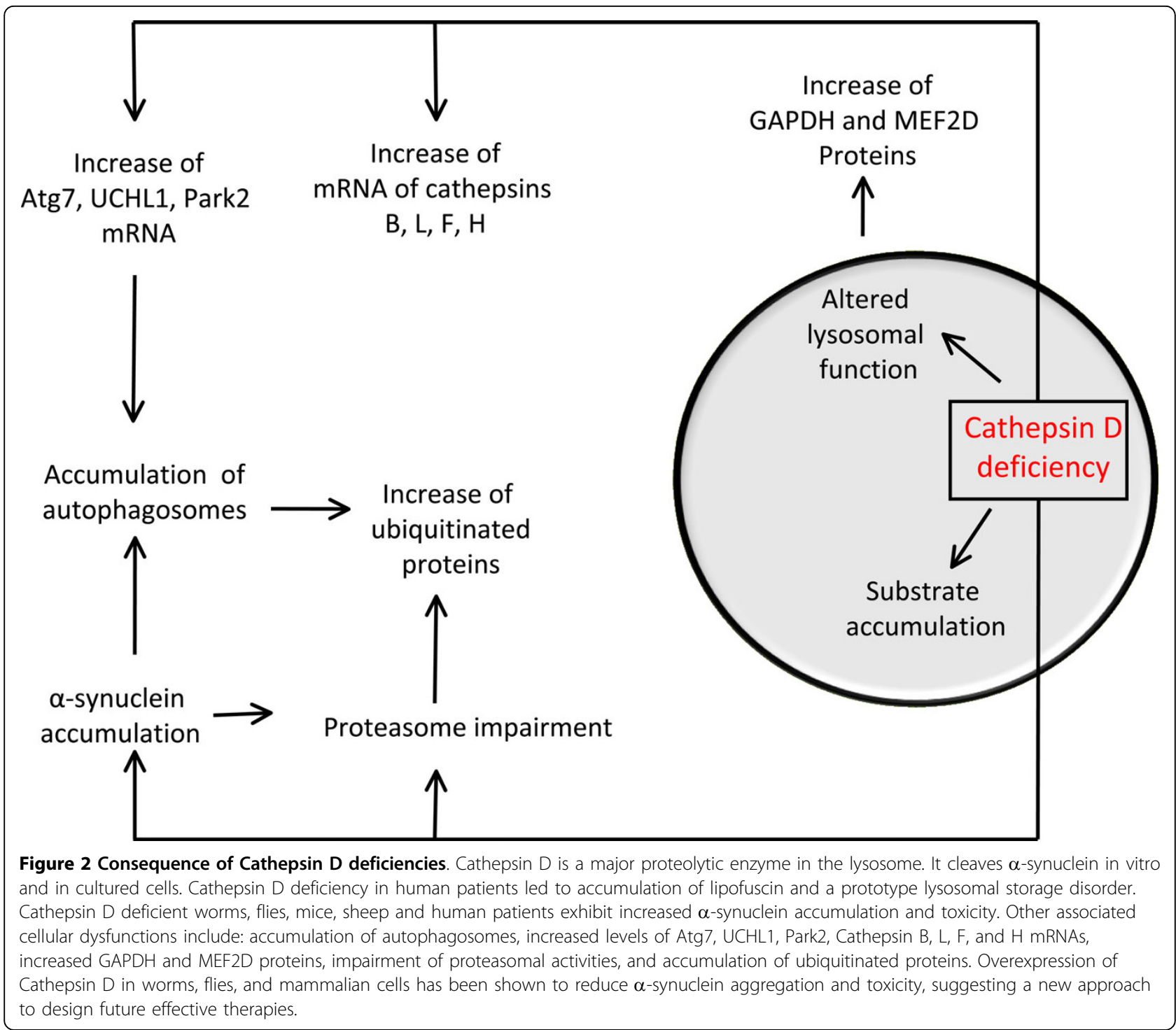

human patients that are associated with Parkinsonism or Parkinson's disease; ii) studies that examined lysosomal protein levels and activities in sporadic Parkinson's disease patients compared to normal controls; and iii) the most extensively studied lysosomal hydrolase, Cathepsin $\mathrm{D}$, in relationship to protein aggregation and toxicity (Figure 2).

\section{i) Parkinson's disease and Parkinsonisms associated with lysosomal mutations}

Parkinsonism has been noted in lysosomal deficiencies such as adult forms of neuronal ceroid lipofuscinosis (ANCL) [129], Gaucher disease [130], and Kufor-Rakeb syndrome [131]. Three types of genetic lysosomal deficiencies have been found to generate Parkinsonism or Parkinson's disease pathologies, including deficiencies in lysosomal membrane function, breaking down of glycolipids and protein degradation. First, loss-of-function of a neuronal lysosomal membrane protein P-type ATPase, ATP13A2, underlies an autosomal recessive form of early-onset Parkinsonism with pyramidal degeneration and dementia (PARK9, Kufor-Rakeb syndrome) [131]. The mutation results in its mis-targeting and endoplasmic reticulum retention. Deficient ATP13A2 may lead to decreased lysosomal acidification and consequent deficient function of the lysosomes.

Second, a relatively large group of deficiencies in sugar or lipid breakdown enzymes are implicated in Parkinsonism and Parkinson's disease pathologies. Genomewide association studies have suggested that mutations in glucocerebrosidase are an important risk factor for Parkinson's and other Lewy body disease $[132,133]$. Deficiencies in glycolipids degradation enzymes, as occurring in Gaucher disease [134], Niemann-Pick disease [135], GM2 gangliosidosis, Tay-Sachs, Sandhoff 
disease, metachromatic leukodystrophy, and beta-galactosialidosis [136], result in $\alpha$-synuclein aggregation in both neurons and glia.

Interestingly, so far out of $\sim 10$ genes known that cause lysosomal storage disease neuronal ceroid lipofuscinosis (NCL), only tripeptidyl peptidase I and Cathepsin $\mathrm{D}$ are proteases. Parkinsonism has been observed in lysosomal tripeptidyl peptidase I deficient patients [137]. Cathepsin D homozygous inactivation in humans causes congenital neuronal ceroid lipofuscinosis (NCL) with postnatal respiratory insufficiency, status epilepticus, and death within hours to weeks after birth [138]. One patient with significant loss of Cathepsin D enzymatic function, due to compound heterozygous missense mutations, developed childhood motor and visual disturbances, cerebral and cerebellar atrophy, and progressive psychomotor disability [139]. In human patients with neuronal ceroid lipofuscinosis (NCL) due to a Cathepsin $\mathrm{D}$ deficiency, the brains were extremely atrophic with massive neuronal loss throughout the cortex, accompanied with intense $\alpha$-synuclein staining [140]. Intense $\alpha$ synuclein immunostaining also exists in the thalamus and basal ganglia [140]. Aggregates with various sizes localized to both proximal axons and the cell soma [140]. Aggregates in the cerebellum were localized to the granular cell layer and deep white matter [140]. Besides Parkinsonism and $\alpha$-synucleinopathy, most of the neuronal ceroid lipofusinosis (NCL) patients' brains exhibit morphologically and biochemically deficient mitochondria [141,142].

\section{ii) Expression levels of lysosomal proteins in Parkinson's disease}

Aging brains exhibit reduced lysosomal function [6]. Increased accumulation of macroautophagic vesicles has been observed in postmortem Alzheimer's and Parkinson's disease patient brains compared to normal controls, consistent with either overproduction of macroautophagic vesicles or a deficit in macroautophagolysosomal clearance [143-146]. Recent studies demonstrated that macroautophagy is efficient in neurons and lysosomal activities are rate-limiting in clearance of protein aggregates [84]. While Loss-of-function of a neuronal lysosomal P-type ATPase, ATP13A2, underlies an autosomal recessive form of early-onset Parkinsonism, ATP13A2 mRNA expression is upregulated in sporadic Parkinson's disease [131]. Interestingly, Cathepsin D protein is upregulated in affected neurons in postmortem brains of patients with Alzheimer's disease; and is accompanied by autophagic vesicle accumulation as identified by immuno-electron microscopy [144,145]. These observations raise the possibility that the upregulation of lysosomal proteins serve as a compensatory mechanism for other lysosomal defects or in response to protein deposition pathology in sporadic Parkinson's disease and Alzheimer's disease [144,147-149]. Alternatively, the accumulation of Cathepsin D protein is a consequence of defects in its trafficking and its own degradation due to other lysosomal defects.

Not many publications directly investigated expression of lysosomal proteins in Parkinson's disease brains. One recent study has found that lysosomal protease Cathepsin D, Lysosome Associated Membrane Protein 1 (LAMP1), and Heat Shock Protein 73 (HSP73) immunoreactivities are significantly decreased (each protein to about 50\%) in Parkinson's disease substantia nigra neurons. The down regulation is more severe in neurons that contained $\alpha$-synuclein inclusions [150]. The accumulation of $\alpha$-synuclein could be a result of impaired clearance by the lysosome via decrease in chaperonemediated-autophagy or specific decrease in Cathepsin D protein levels.

Overexpression of mutant human $\alpha$-synuclein in cultured cells induces lysosomal dysfunction, accumulation of autophagosomes and many of these accumulated autophagosomes contain engulfed mitochondria [151]. Furthermore, Parkinson's disease causing A53T, A30P mutant $\alpha$-synuclein, or S129 site phosphorylated $\alpha$-synuclein blocks chaperone-mediated-autophagic activity $[127,152]$. Overexpression of mutant human $\alpha$-synuclein in the rat substantia nigra using viral vectors leads to reduction of Lysosome Associated Membrane Protein 1 (LAMP1), and Heat Shock Protein 73 (HSP73) levels in neurons with $\alpha$-synuclein immunoreactive inclusions. Interestingly, mutant $\alpha$-synuclein expressing rat neurons without inclusions exhibit higher Cathepsin D immunoreactivity compared to controls. One interpretation is that an early and effective enhancement of Cathepsin D expression in a subset of neurons delays or attenuates the accumulation of $\alpha$-synuclein. The subset of neurons unable to enhance Cathepsin D activity consequently suffers from a vicious cycle of $\alpha$-synuclein accumulation and further reduction of Cathepsin D [150].

\section{iii) Cathepsin D deficiency in vitro and in animal models}

Cathepsin D is the principal lysosomal aspartate protease and a main endopeptidase. Cathepsin D is synthesized as a prepropeptide of $51 \mathrm{kDa}$, once the signal peptide is cleaved upon Cathepsin $\mathrm{D}$ insertion into the endoplasmic reticulum the resultant propeptide is 49 $\mathrm{kDa}$. It has been shown that Cathepsin D is delivered to the lysosome via the mannose-6-phosphate receptor (M6Pr)-dependent pathway, however it can also be delivered to the lysosome in a mannose-6-phosphate receptor (M6Pr)-independent manner via binding to sortilin (67). The Cathepsin D zymogen is then activated in the acidic lysosomal environment [153]. Its yeast homolog, PEP4, plays a critical role in maturation of other vacuolar proteases, total cellular protein turnover 
under normal and nutrient-deprived conditions, and total cellular protein turnover in response to oxidative stress [154-157].

Cathepsin D knockout (ctsd-/-) mice die at approximately postnatal day 26 (P26), secondary to a combination of nervous system and systemic abnormalities, including both accumulation of autophagic vacuoles at as early as postnatal day 0 (P0). These $c t s d-/$-mice exhibit seizures, unsteady posture, and smaller brains. No overt loss of substantia nigra dopaminergic neurons was observed, likely due to the young age [158-162]. Significantly, $\alpha$-synuclein accumulation in neuronal cell bodies has been found in P25 ctsd-/- but not wildtype cortex [163]. In keeping with these observations, elevated levels of high molecular weight but not monomeric $\alpha$-synuclein, and high molecular weight ubiquitinated proteins have been found in extracts from the cortex of $c t s d-/$ - mice but not wildtype mice; these findings are reminiscent of what is seen in Lewy body diseases. The cytoplasmic microtubule-associated protein, tau, or the synaptic protein, synaptophysin, did not accumulate in ctsd-/- cortex compared to wildtype cortex [163], suggesting that Cathepsin D deficiency at P25 does not have a general effect on the accumulation of all cytoplasmic and synaptic proteins.

In contrast to the brains of human lipidoses patients [136], where $\alpha$-synuclein aggregates are found in both neurons and glia and co-localize with lipids, in ctsd-/brains $\alpha$-synuclein accumulations do not co-localize with autofluorescent lipofuscin. Furthermore, $\alpha$-synuclein accumulations in $c t s d-/$ - brains are present in neurons but not in astrocytes. In a relatively small fraction of neurons $(\sim 5 \%)$, prominent accumulations of $\alpha$-synuclein immunoreactivity co-localize with intense ubiquitin staining, consistent with the observation that a small fraction of $\alpha$-synuclein in Lewy bodies is ubiquitinated $[164,165]$. Along similar lines of increased autophagy in ctsd-/- mice, an increase in mRNA encoding autophagy related proteins Atg7, Parkinson's disease genes UCHL1 and Park2, as well as Cathepsins B, L, F, and $\mathrm{H}$ has been observed. In addition, substrates for chaperonemediated-autophagy, GAPDH and MEF2D proteins, are increased in $c t s d-/-$ mice, suggesting a reduction of chaperone-mediated-autophagy $[163,166]$. In a worm model, Cathepsin D reduction by siRNA exacerbates $\alpha$ synuclein aggregation from transgenic expression of a human $\alpha$-synuclein gene [163]. Figure 2 summarizes the effects of Cathepsin D deficiency on autophagy and $\alpha$ synuclein accumulation. As one major lysosomal acid hydrolase, Cathepsin D deficiency likely contributed to the accumulation of lysosomal storage of lipofuscins in the Cathepsin D deficient brains. Although has not been directly tested, other aspects of lysosomal function, such as lysosomal membrane property, ability of the lysosomes to fuse with autophagosomes, and the efficiency of the lysosomes to export degradation products, may also be affected as an indirectly consequence of Cathepsin D deficiency.

In a parallel study, Cullen et al investigated $\alpha$-synuclein immunoreactivity in a number of species deficient in Cathepsin D [140]. Detailed immunohistochemical studies have found that in Cathepsin D-deficient mice, $\alpha$-synuclein accumulation occurs in neurons from the deep cortical laminae, superior colliculus, subiculum, thalamus, deep cerebellar nuclei, and the white matter tracts. In Cathepsin D-deficient sheep, widespread axonal swelling in deep white matter tracts, and isolated $\alpha$ synuclein aggregates in the thalamus have been found. In transgenic flies that express human $\alpha$-synuclein, Cathepsin D deficiency exacerbated retinal degeneration.

Cathepsin D knockout mice have the most severe phenotypes of all cathepsin knockouts. In mice, Cathepsin F deficiency leads to phenotypes resembling late onset neuronal ceroid lipofuscinosis (NCL) [167]. Cathepsin B and $\mathrm{L}$ appear to be able to compensate for each other in the nervous system to a certain extent. In support of this conclusion, mice with deficiencies in both Cathepsin $B$ and $L$ genes exhibit phenotypes resembling mice with single deficiency of Cathepsin D [158].

\section{Upregulation of lysosomal genes as a potential therapeutic approach against Parkinson's disease}

Enhancing autophagy can reduce protein aggregation in a number of cellular models of neurodegenerative diseases [168-174]. The effects of enhancing macroautophagy at distinct steps can be additive in enhancing protein degradation [175]. There are two limitations to this approach. First, because both macroautophagy and chaperonemediated-autophagy are dependent on intact lysosomes, it is essential that lysosomal activities are preserved to be effective in clearing potentially neurotoxic proteins. Second, enhancing overall macroautophagy may be detrimental because of the risk of reducing normal proteins. In comparison, enhancing lysosomal function may have the advantage of increasing the efficiency of turnover of autophagosome-sequestered damaged proteins and organelles, without sacrificing selectivity for degradation of toxic or dysfunctional cellular materials. Studying upregulation of lysosomal genes as a potential therapeutic approach against Parkinson's disease has just recently come to play, and is of limited scale. Thus, we focus this part of our review on the study of Cathepsin D.

\section{3a. Reduction of $\alpha$-synuclein by Cathepsin D}

Mammalian Cathepsin D recognizes $\alpha$-synuclein at Y125 in vitro [176]. Nitration and phosphorylation of $\alpha$ synuclein at Y125 have been observed in cultured cells although whether these changes are required for initiation of $\alpha$-synucleinopathy is unclear [177-181]. 
Studies using Cathepsin D inhibitors and siRNA demonstrated that lysosomal Cathepsin D is the most active in degradation of $\alpha$-synuclein [178]. In an aggregation assay in $\mathrm{H} 4$ neuroglioma cells, co-over-expression of synphilin and an $\alpha$-synuclein-green fluorescent protein (GFP) fusion protein ( $\alpha$-synuclein-GFP) forms visible aggregates in transfected $\mathrm{H} 4$ cells [182]. Transfection of Cathepsin D gene (CTSD) together with $\alpha$-synucleinGFP and synphilin reduces $\alpha$-synuclein aggregates [163]. Immunocytochemistry studies indicated that the effects of Cathepsin D on reduction of $\alpha$-synuclein aggregation are likely due to reduction of $\alpha$-synuclein rather than secondary to a reduction in synphilin levels [163]. By transfecting Cathepsin D gene (CTSD) in a rodent cell line of mesencephalic origin MES23.5, Cullen et al have found that Cathepsin D is effective in reducing both the wildtype and 7 different mutant forms of $\alpha$-synuclein: the three Parkinson's disease-linked mutant A30P, A53T and E46K, the serine 129 mutant S129A and S129D, as well as the D98A and Q99A mutant abolishing chaperonemediated-autophagy [140].

Excessive $\alpha$-synuclein induces neuron death in cell cultures, and in a variety of genetic and viral deliverybased animal models [33,34,183,184]. Overexpression of $\alpha$-synuclein-GFP induced robust cell death in SH-SY5Y cells. Co-transfection of human Cathepsin D provided significant protection against $\alpha$-synuclein-GFP overexpression-induced cell death. Cathepsin D has a known specificity for hydrophobic residues [176]. Although $\alpha$ synuclein contains many putative Cathepsin D cleavage sites, Y125 is the primary site of cleavage [176]. We found that Cathepsin D is also protective against cell death induced by mutant $\alpha$-synuclein (A30P and A53T) in SH-SY5Y cells. In contrast, mutating $\alpha$-synuclein at Y125 [176] results in an $\alpha$-synuclein mutant that induces cell death and resists neuroprotection by elevated Cathepsin D. Furthermore, Cathepsin D is ineffective at attenuating chloroquine-or staurosporine-induced cell death. In C. elegans, overexpression of wildtype Cathepsin D, but not Cathepsin D enzymatic mutants, Cathepsin B or Cathepsin L, protects against $\alpha$-synuclein toxicity, indicating a conserved mechanism of Cathepsin D in cytoprotection [163].

Other lysosomal proteins have been shown to protect against $\alpha$-synuclein toxicity include ATP13A2 [185], a protein that may be involved in maintaining lysosomal acidic environment. As mentioned above, transcription factor EB (TFEB) elicits a coordinated upregulation of genes involved in lysosomal activities and transporting substrates to the lysosomes [87]. TFEB overexpression has been shown to reduce mutant Huntingtin load in a rat striatal cell line, HD43 cells [87]. These findings will surely inspire a series of future studies to determine whether these and other proteins involved in lysosomal function can provide novel therapies against Parkinson's and other neurodegenerative diseases.

\section{Conclusions and perspectives}

Neurons are non-dividing and rarely replenishing cells that cannot distribute accumulated by-products through mitosis, thus needing a diligent cleaning system for maintenance of cell health. Lysosomes are the major sites for degrading aged proteins and organelles. Thus lysosomes are essential for cells to maintain proper protein and organelle quantity and quality, and of primary importance in the context of avoiding neurodegenerative diseases, including Parkinson's disease. As such, many genetic mutations with dysfunctional lysosomes lead to neurological diseases, including Parkinsonism and Parkinson's pathogenesis. Fortunately, the finding that lysosomal activities are rate-limiting in degradation of aged and damaged proteins and organelles provides an opportunity to examine the potential of upregulating lysosomal activities to help prevent, attenuate or even reverse the manifestation of Parkinson's disease. The observation that lysosomal activities can be regulated at the level of transcription, trafficking, processing and activation offers a number of potential approaches to develop therapeutic strategies for neurodegenerative diseases.

\section{Abbreviations \\ (AAV): adeno-associated virus; (CD): Cathepsin D; (ER): endoplasmic reticulum; (LAMP-2a): Iysosomal-associated membrane protein 2a; (LIMP-2): lysosomal integral membrane protein-2; (M6Pr): mannose-6phosphate receptor; (mitophagy): autophagy of mitochondria; (MPP+): 1-methyl-4- phenylpyridinium; (MPTP): 1-methyl 4-phenyl 1,2,3,6-tetrahydropyridine; (PD): Parkinson's disease; (TFEB): transcription factor EB.}

\section{Acknowledgements}

This work is supported by a grant from the Michael J Fox foundation and a UAB startup fund to Dr. Jianhua Zhang. We are grateful to Drs. Steve Carroll, Victor Darley-Usmar and John Shacka for their helpful discussions of the concepts presented in this review.

\section{Authors' contributions}

LS and JZ wrote the review. All authors have read and approved the final manuscript.

\section{Competing interests}

The authors declare that they have no competing interests.

Received: 20 January 2010 Accepted: 13 April 2010

Published: 13 April 2010

\section{References}

1. de DC: The lysosome turns fifty. Nat Cell Biol 2005, 7:847-849.

2. Fuertes G, Martin de Llano JJ, Villarroya A, Rivett AJ, Knecht E: Changes in the proteolytic activities of proteasomes and lysosomes in human fibroblasts produced by serum withdrawal, amino-acid deprivation and confluent conditions. Biochem J 2003, 375:75-86.

3. Cuervo AM, Dice JF: Lysosomes, a meeting point of proteins, chaperones, and proteases. J Mol Med 1998, 76:6-12.

4. Mortimore GE, Poso AR, Lardeux BR: Mechanism and regulation of protein degradation in liver. Diabetes Metab Rev 1989, 5:49-70.

5. Nixon RA, Yang DS, Lee JH: Neurodegenerative lysosomal disorders: a continuum from development to late age. Autophagy 2008, 4:590-599. 
6. Cuervo AM, Dice JF: When lysosomes get old. Exp Gerontol 2000, 35:119-131.

7. Lee VM, Trojanowski JQ: Mechanisms of Parkinson's disease linked to pathological alpha-synuclein: new targets for drug discovery. Neuron 2006, 52:33-38.

8. Singleton $A B$, Farrer $M$, Johnson J, Singleton A, Hague S, Kachergus J, et al: alpha-Synuclein locus triplication causes Parkinson's disease. Science 2003, 302:841

9. Giasson Bl, Jakes R, Goedert M, Duda JE, Leight $\mathrm{S}$, Trojanowski JQ, et al: A panel of epitope-specific antibodies detects protein domains distributed throughout human alpha-synuclein in Lewy bodies of Parkinson's disease. J Neurosci Res 2000, 59:528-533.

10. Spillantini MG, Schmidt ML, Lee VM, Trojanowski JQ, Jakes R, Goedert M: Alpha-synuclein in Lewy bodies. Nature 1997, 388:839-840.

11. Klivenyi P, Siwek D, Gardian G, Yang L, Starkov A, Cleren C, et al: Mice lacking alpha-synuclein are resistant to mitochondrial toxins. Neurobiol Dis 2006, 21:541-548.

12. Drolet RE, Behrouz B, Lookingland KJ, Goudreau JL: Mice lacking alphasynuclein have an attenuated loss of striatal dopamine following prolonged chronic MPTP administration. Neurotoxicology 2004, 25:761-769.

13. Robertson DC, Schmidt O, Ninkina N, Jones PA, Sharkey J, Buchman VL: Developmental loss and resistance to MPTP toxicity of dopaminergic neurones in substantia nigra pars compacta of gamma-synuclein, alphasynuclein and double alpha/gamma-synuclein null mutant mice. J Neurochem 2004, 89:1126-1136.

14. Dauer W, Kholodilov N, Vila M, Trillat AC, Goodchild R, Larsen KE, et al: Resistance of alpha -synuclein null mice to the parkinsonian neurotoxin MPTP. Proc Natl Acad Sci USA 2002, 99:14524-14529.

15. Hayashita-Kinoh H, Yamada M, Yokota T, Mizuno Y, Mochizuki H: Downregulation of alpha-synuclein expression can rescue dopaminergic cells from cell death in the substantia nigra of Parkinson's disease rat model. Biochem Biophys Res Commun 2006, 341:1088-1095.

16. Thomas B, Beal MF: Parkinson's disease. Hum Mol Genet 2007, 16(Spec No 2):R183-R194.

17. Mihajlovic M, Lazaridis T: Membrane-bound structure and energetics of alpha-synuclein. Proteins 2008, 70:761-778.

18. Jao CC, Hegde BG, Chen J, Haworth IS, Langen R: Structure of membranebound alpha-synuclein from site-directed spin labeling and computational refinement. Proc Natl Acad Sci USA 2008, 105:19666-19671.

19. Pandey AP, Haque F, Rochet JC, Hovis JS: Clustering of alpha-synuclein on supported lipid bilayers: role of anionic lipid, protein, and divalent ion concentration. Biophys J 2009, 96:540-551.

20. Volles MJ, Lansbury PT Jr: Relationships between the sequence of alphasynuclein and its membrane affinity, fibrillization propensity, and yeast toxicity. J Mol Biol 2007, 366:1510-1522.

21. Zakharov SD, Hulleman JD, Dutseva EA, Antonenko YN, Rochet JC, Cramer WA: Helical alpha-synuclein forms highly conductive ion channels. Biochemistry 2007, 46:14369-14379.

22. Kubo S, Nemani VM, Chalkley RJ, Anthony MD, Hattori N, Mizuno Y, et al: A combinatorial code for the interaction of alpha-synuclein with membranes. J Biol Chem 2005, 280:31664-31672.

23. Rochet JC, Outeiro TF, Conway KA, Ding TT, Volles MJ, Lashuel HA, et al: Interactions among alpha-synuclein, dopamine, and biomembranes: some clues for understanding neurodegeneration in Parkinson's disease. J Mol Neurosci 2004, 23:23-34.

24. Zhu M, Li J, Fink AL: The association of alpha-synuclein with membranes affects bilayer structure, stability, and fibril formation. J Biol Chem 2003, 278:40186-40197.

25. Zhu M, Fink AL: Lipid binding inhibits alpha-synuclein fibril formation. $J$ Biol Chem 2003, 278:16873-16877.

26. Cabin DE, Shimazu K, Murphy D, Cole NB, Gottschalk W, Mcllwain KL, et al: Synaptic vesicle depletion correlates with attenuated synaptic responses to prolonged repetitive stimulation in mice lacking alpha-synuclein. $J$ Neurosci 2002, 22:8797-8807.

27. Abeliovich A, Schmitz Y, Farinas I, Choi-Lundberg D, Ho WH, Castillo PE, et al: Mice lacking alpha-synuclein display functional deficits in the nigrostriatal dopamine system. Neuron 2000, 25:239-252.

28. Sharon R, Bar-Joseph I, Mirick GE, Serhan CN, Selkoe DJ: Altered fatty acid composition of dopaminergic neurons expressing alpha-synuclein and human brains with alpha-synucleinopathies. J Biol Chem 2003, 278:49874-49881.
29. Fortin DL, Nemani VM, Voglmaier SM, Anthony MD, Ryan TA, Edwards RH: Neural activity controls the synaptic accumulation of alpha-synuclein. $J$ Neurosci 2005, 25:10913-10921.

30. George JM, Jin H, Woods WS, Clayton DF: Characterization of a novel protein regulated during the critical period for song learning in the zebra finch. Neuron 1995, 15:361-372.

31. Perlmutter JD, Braun AR, Sachs JN: Curvature dynamics of alpha-synuclein familial Parkinson disease mutants: molecular simulations of the micelleand bilayer-bound forms. J Biol Chem 2009, 284:7177-7189.

32. Martin $L$, Pan Y, Price AC, Sterling W, Copeland NG, Jenkins NA, et al: Parkinson's disease alpha-synuclein transgenic mice develop neuronal mitochondrial degeneration and cell death. J Neurosci 2006, 26:41-50.

33. Giasson BI, Duda JE, Quinn SM, Zhang B, Trojanowski JQ, Lee VM: Neuronal alpha-synucleinopathy with severe movement disorder in mice expressing A53T human alpha-synuclein. Neuron 2002, 34:521-533.

34. Masliah E, Rockenstein E, Veinbergs I, Mallory M, Hashimoto M, Takeda A, et al: Dopaminergic loss and inclusion body formation in alpha-synuclein mice: implications for neurodegenerative disorders. Science 2000, 287:1265-1269.

35. Clough RL, Dermentzaki G, Stefanis L: Functional dissection of the alphasynuclein promoter: transcriptional regulation by ZSCAN21 and ZNF219. J Neurochem 2009, 110:1479-1490.

36. Clough RL, Stefanis L: A novel pathway for transcriptional regulation of alpha-synuclein. FASEB J 2007, 21:596-607

37. Scherzer CR, Grass JA, Liao Z, Pepivani I, Zheng B, Eklund AC, et al: GATA transcription factors directly regulate the Parkinson's disease-linked gene alpha-synuclein. Proc Natl Acad Sci USA 2008, 105:10907-10912.

38. Nuber S, Petrasch-Parwez E, Winner B, Winkler J, von HS, Schmidt T, et al: Neurodegeneration and motor dysfunction in a conditional model of Parkinson's disease. J Neurosci 2008, 28:2471-2484.

39. Masliah E, Rockenstein E, Adame A, Alford M, Crews L, Hashimoto M, et al: Effects of alpha-synuclein immunization in a mouse model of Parkinson's disease. Neuron 2005, 46:857-868.

40. Cantuti-Castelvetri I, Klucken J, Ingelsson M, Ramasamy K, McLean PJ, Frosch MP, et al: Alpha-synuclein and chaperones in dementia with Lewy bodies. J Neuropathol Exp Neurol 2005, 64:1058-1066.

41. Li W, Lesuisse C, Xu Y, Troncoso JC, Price DL, Lee MK: Stabilization of alpha-synuclein protein with aging and familial parkinson's diseaselinked A53T mutation. J Neurosci 2004, 24:7400-7409.

42. Schapira AH, Cooper JM, Dexter D, Jenner P, Clark JB, Marsden CD: Mitochondrial complex I deficiency in Parkinson's disease. Lancet 1989, 1:1269.

43. Keeney PM, Xie J, Capaldi RA, Bennett JP Jr: Parkinson's disease brain mitochondrial complex I has oxidatively damaged subunits and is functionally impaired and misassembled. J Neurosci 2006, 26:5256-5264.

44. Parker WD Jr, Parks JK, Swerdlow RH: Complex I deficiency in Parkinson's disease frontal cortex. Brain Res 2008, 1189:215-218.

45. Smigrodzki R, Parks J, Parker WD: High frequency of mitochondrial complex I mutations in Parkinson's disease and aging. Neurobiol Aging 2004, 25:1273-1281.

46. Arthur CR, Morton SL, Dunham LD, Keeney PM, Bennett JP Jr: Parkinson's disease brain mitochondria have impaired respirasome assembly, agerelated increases in distribution of oxidative damage to mtDNA and no differences in heteroplasmic mtDNA mutation abundance. $\mathrm{Mo}$ Neurodegener 2009, 4:37.

47. Bender A, Krishnan KJ, Morris CM, Taylor GA, Reeve AK, Perry RH, et al: High levels of mitochondrial DNA deletions in substantia nigra neurons in aging and Parkinson disease. Nat Genet 2006, 38:515-517.

48. Simon DK, Lin MT, Zheng L, Liu GJ, Ahn CH, Kim LM, et al: Somatic mitochondrial DNA mutations in cortex and substantia nigra in aging and Parkinson's disease. Neurobiol Aging 2004, 25:71-81.

49. Soong NW, Hinton DR, Cortopassi G, Arnheim N: Mosaicism for a specific somatic mitochondrial DNA mutation in adult human brain. Nat Genet 1992, 2:318-323.

50. Corral-Debrinski M, Horton T, Lott MT, Shoffner JM, Beal MF, Wallace DC: Mitochondrial DNA deletions in human brain: regional variability and increase with advanced age. Nat Genet 1992, 2:324-329.

51. Stokin GB, Lillo C, Falzone TL, Brusch RG, Rockenstein E, Mount SL, et al: Axonopathy and transport deficits early in the pathogenesis of Alzheimer's disease. Science 2005, 307:1282-1288. 
52. Li H, Li SH, Yu ZX, Shelbourne P, Li XJ: Huntingtin aggregate-associated axonal degeneration is an early pathological event in Huntington's disease mice. J Neurosci 2001, 21:8473-8481.

53. Galvin JE, Uryu K, Lee VM, Trojanowski JQ: Axon pathology in Parkinson's disease and Lewy body dementia hippocampus contains alpha-, beta-, and gamma-synuclein. Proc Natl Acad Sci USA 1999, 96:13450-13455.

54. Braak H, Ghebremedhin E, Rub U, Bratzke H, Del TK: Stages in the development of Parkinson's disease-related pathology. Cell Tissue Res 2004, 318:121-134.

55. Langston JW, Ballard P: Parkinsonism induced by 1-methyl-4-phenyl1,2,3,6-tetrahydropyridine (MPTP): implications for treatment and the pathogenesis of Parkinson's disease. Can J Neurol Sci 1984, 11:160-165.

56. Langston JW, Langston EB, Irwin I: MPTP-induced parkinsonism in human and non-human primates-clinical and experimental aspects. Acta Neurol Scand Supp/ 1984, 100:49-54.

57. Langston JW, Ballard PA Jr: Parkinson's disease in a chemist working with 1-methyl-4-phenyl-1,2,5,6-tetrahydropyridine. N Engl J Med 1983, 309:310.

58. Langston JW, Ballard P, Tetrud JW, Irwin I: Chronic Parkinsonism in humans due to a product of meperidine-analog synthesis. Science 1983, 219:979-980.

59. Bove J, Prou D, Perier C, Przedborski S: Toxin-induced models of Parkinson's disease. NeuroRx 2005, 2:484-494.

60. Langston JW, Irwin I, Langston EB, Forno LS: 1-Methyl-4-phenylpyridinium ion (MPP+): identification of a metabolite of MPTP, a toxin selective to the substantia nigra. Neurosci Lett 1984, 48:87-92.

61. Betarbet R, Sherer TB, MacKenzie G, Garcia-Osuna M, Panov AV, Greenamyre JT: Chronic systemic pesticide exposure reproduces features of Parkinson's disease. Nat Neurosci 2000, 3:1301-1306.

62. Sherer TB, Betarbet R, Stout AK, Lund S, Baptista M, Panov AV, et al: An in vitro model of Parkinson's disease: linking mitochondrial impairment to altered alpha-synuclein metabolism and oxidative damage. J Neurosci 2002, 22:7006-7015.

63. Gao HM, Liu B, Hong JS: Critical role for microglial NADPH oxidase in rotenone-induced degeneration of dopaminergic neurons. J Neurosci 2003, 23:6181-6187.

64. Sherer TB, Betarbet R, Testa CM, Seo BB, Richardson JR, Kim JH, et al: Mechanism of toxicity in rotenone models of Parkinson's disease. $J$ Neurosci 2003, 23:10756-10764.

65. Trimmer PA, Bennett JP Jr: The cybrid model of sporadic Parkinson's disease. Exp Neurol 2009, 218:320-325.

66. Trimmer PA, Borland MK, Keeney PM, Bennett JP Jr, Parker WD Jr: Parkinson's disease transgenic mitochondrial cybrids generate Lewy inclusion bodies. J Neurochem 2004, 88:800-812.

67. Ekstrand Ml, Terzioglu M, Galter D, Zhu S, Hofstetter C, Lindqvist E, et al: Progressive parkinsonism in mice with respiratory-chain-deficient dopamine neurons. Proc Natl Acad Sci USA 2007, 104:1325-1330.

68. Schapira AH: Mitochondria in the aetiology and pathogenesis of Parkinson's disease. Lancet Neurol 2008, 7:97-109.

69. Nakamura K, Nemani VM, Wallender EK, Kaehlcke K, Ott M, Edwards RH: Optical reporters for the conformation of alpha-synuclein reveal a specific interaction with mitochondria. J Neurosci 2008, 28:12305-12317.

70. Devi L, Raghavendran V, Prabhu BM, Avadhani NG, Anandatheerthavarada HK: Mitochondrial import and accumulation of alpha-synuclein impair complex I in human dopaminergic neuronal cultures and Parkinson disease brain. J Biol Chem 2008, 283:9089-9100.

71. Parihar MS, Parihar A, Fujita M, Hashimoto M, Ghafourifar P: Mitochondrial association of alpha-synuclein causes oxidative stress. Cell Mol Life Sci 2008, 65:1272-1284.

72. Song DD, Shults CW, Sisk A, Rockenstein E, Masliah E: Enhanced substantia nigra mitochondrial pathology in human alpha-synuclein transgenic mice after treatment with MPTP. Exp Neurol 2004, 186:158-172.

73. Elkon H, Don J, Melamed E, Ziv I, Shirvan A, Offen D: Mutant and wild-type alpha-synuclein interact with mitochondrial cytochrome $\mathrm{C}$ oxidase. $J \mathrm{Mol}$ Neurosci 2002, 18:229-238.

74. Vila M, Vukosavic S, Jackson-Lewis V, Neystat $M$, Jakowec M, Przedborski S: Alpha-synuclein up-regulation in substantia nigra dopaminergic neurons following administration of the parkinsonian toxin MPTP. J Neurochem 2000, 74:721-729.
75. Meredith GE, Totterdell S, Potashkin JA, Surmeier DJ: Modeling PD pathogenesis in mice: advantages of a chronic MPTP protocol. Parkinsonism Relat Disord 2008, 14(Suppl 2):S112-S115.

76. Meredith GE, Halliday GM, Totterdell S: A critical review of the development and importance of proteinaceous aggregates in animal models of Parkinson's disease: new insights into Lewy body formation. Parkinsonism Relat Disord 2004, 10:191-202.

77. Meredith GE, Totterdell S, Petroske E, Santa CK, Callison RC Jr, Lau YS: Lysosomal malfunction accompanies alpha-synuclein aggregation in a progressive mouse model of Parkinson's disease. Brain Res 2002, 956:156-165.

78. Jackson-Lewis V, Przedborski S: Protocol for the MPTP mouse model of Parkinson's disease. Nat Protoc 2007, 2:141-151.

79. Petroske E, Meredith GE, Callen S, Totterdell S, Lau YS: Mouse model of Parkinsonism: a comparison between subacute MPTP and chronic MPTP/probenecid treatment. Neuroscience 2001, 106:589-601.

80. Fountaine TM, Wade-Martins R: RNA interference-mediated knockdown of alpha-synuclein protects human dopaminergic neuroblastoma cells from MPP(+) toxicity and reduces dopamine transport. J Neurosci Res 2007, 85:351-363.

81. Yu WH, Matsuoka Y, Sziraki I, Hashim A, LaFrancois J, Sershen $H$, et al: Increased dopaminergic neuron sensitivity to 1-methyl-4-phenyl-1,2,3,6tetrahydropyridine (MPTP) in transgenic mice expressing mutant A53T alpha-synuclein. Neurochem Res 2008, 33:902-911.

82. Nieto M, Gil-Bea FJ, Dalfo E, Cuadrado M, Cabodevilla F, Sanchez B, et al: Increased sensitivity to MPTP in human alpha-synuclein A30P transgenic mice. Neurobiol Aging 2006, 27:848-856.

83. Settembre C, Fraldi A, Rubinsztein DC, Ballabio A: Lysosomal storage diseases as disorders of autophagy. Autophagy 2008, 4:113-114.

84. Boland B, Kumar A, Lee S, Platt FM, Wegiel J, Yu WH, et al: Autophagy induction and autophagosome clearance in neurons: relationship to autophagic pathology in Alzheimer's disease. J Neurosci 2008, 28:6926-6937.

85. Lubke T, Lobel P, Sleat DE: Proteomics of the lysosome. Biochim Biophys Acta 2009, 1793:625-635.

86. Wang F, Duan R, Chirgwin J, Safe SH: Transcriptional activation of cathepsin D gene expression by growth factors. J Mol Endocrinol 2000, 24:193-202.

87. Sardiello M, Palmieri M, di RA, Medina DL, Valenza M, Gennarino VA, et al: A gene network regulating lysosomal biogenesis and function. Science 2009, 325:473-477.

88. Erickson $\mathrm{AH}$, Conner $\mathrm{GE}$, Blobel $\mathrm{G}$ : Biosynthesis of a lysosomal enzyme. Partial structure of two transient and functionally distinct $\mathrm{NH} 2$-terminal sequences in cathepsin D. J Biol Chem 1981, 256:11224-11231.

89. Erickson $\mathrm{AH}$, Blobel $\mathrm{G}$ : Early events in the biosynthesis of the lysosomal enzyme cathepsin D. J Biol Chem 1979, 254:11771-11774.

90. Qian Y, Lee I, Lee WS, Qian M, Kudo M, Canfield WM, et al: Functions of the alpha, beta and gamma subunits of UDP-GICNAc:lysosomal enzyme $\mathrm{N}$-acetylglucosamine-1-phosphotransferase. J Biol Chem 2009, 285:3360-3370.

91. Kudo M, Brem MS, Canfield WM: Mucolipidosis II (I-cell disease) and mucolipidosis IIIA (classical pseudo-hurler polydystrophy) are caused by mutations in the GIcNAc-phosphotransferase alpha/beta -subunits precursor gene. Am J Hum Genet 2006, 78:451-463.

92. Kudo M, Bao M, D'Souza A, Ying F, Pan H, Roe BA, et al: The alpha- and beta-subunits of the human UDP-N-acetylglucosamine:lysosomal enzyme $\mathrm{N}$-acetylglucosamine-1-phosphotransferase [corrected] are encoded by a single cDNA. J Biol Chem 2005, 280:36141-36149.

93. Braulke T, Bonifacino JS: Sorting of lysosomal proteins. Biochim Biophys Acta 2009, 1793:605-614.

94. Reczek D, Schwake M, Schroder J, Hughes H, Blanz J, Jin X, et al: LIMP-2 is a receptor for lysosomal mannose-6-phosphate-independent targeting of beta-glucocerebrosidase. Cell 2007, 131:770-783.

95. Lefrancois S, Zeng J, Hassan AJ, Canuel M, Morales CR: The lysosomal trafficking of sphingolipid activator proteins (SAPs) is mediated by sortilin. EMBO J 2003, 22:6430-6437.

96. Canuel M, Korkidakis A, Konnyu K, Morales CR: Sortilin mediates the lysosomal targeting of cathepsins $\mathrm{D}$ and $\mathrm{H}$. Biochem Biophys Res Commun 2008, 373:292-297. 
97. Canuel M, Libin Y, Morales CR: The interactomics of sortilin: an ancient lysosomal receptor evolving new functions. Histol Histopathol 2009, 24:481-492.

98. Zeng J, Racicott J, Morales CR: The inactivation of the sortilin gene leads to a partial disruption of prosaposin trafficking to the lysosomes. Exp Cell Res 2009, 315:3112-3124

99. Blanz J, Groth J, Zachos C, Wehling C, Saftig P, Schwake M: Disease-causing mutations within the lysosomal integral membrane protein type 2 (LIMP-2) reveal the nature of binding to its ligand \{beta\}glucocerebrosidase. Hum Mol Genet 2010, 19:563-72.

100. Griffiths GM: Gaucher disease: forging a new path to the lysosome. Cell 2007, 131:647-649.

101. Berkovic SF, Dibbens LM, Oshlack A, Silver JD, Katerelos M, Vears DF, et al: Array-based gene discovery with three unrelated subjects shows SCARB2/LIMP-2 deficiency causes myoclonus epilepsy and glomerulosclerosis. Am J Hum Genet 2008, 82:673-684.

102. Grear KE, Ling IF, Simpson JF, Furman JL, Simmons CR, Peterson SL, et al: Expression of SORL1 and a novel SORL1 splice variant in normal and Alzheimers disease brain. Mol Neurodegener 2009, 4:46.

103. Minarowska A, Karwowska A, Gacko M: Quantitative determination and localization of cathepsin D and its inhibitors. Folia Histochem Cytobiol 2009, 47:153-177.

104. Turk V, Stoka V, Turk D: Cystatins: biochemical and structural properties, and medical relevance. Front Biosci 2008, 13:5406-5420.

105. Gacko M, Minarowska A, Karwowska A, Minarowski L: Cathepsin D inhibitors. Folia Histochem Cytobiol 2007, 45:291-313.

106. Fischer $E P$, Holzer $\mathrm{H}$ : Interaction of proteinases and their inhibitors from yeast. Activation of carboxypeptidase Y. Biochim Biophys Acta 1980, 615:187-198.

107. Heinrich M, Wickel M, Winoto-Morbach S, Schneider-Brachert W, Weber T, Brunner J, et al: Ceramide as an activator lipid of cathepsin D. Adv Exp Med Biol 2000, 477:305-315.

108. Noda T, Fujita N, Yoshimori T: The late stages of autophagy: how does the end begin? Cell Death Differ 2009, 16:984-990.

109. Kimura S, Noda T, Yoshimori T: Dissection of the autophagosome maturation process by a novel reporter protein, tandem fluorescenttagged LC3. Autophagy 2007, 3:452-460.

110. Lucocq J, Walker D: Evidence for fusion between multilamellar endosomes and autophagosomes in HeLa cells. Eur J Cell Biol 1997, 72:307-313.

111. Kalatzis V, Nevo N, Cherqui S, Gasnier B, Antignac C: Molecular pathogenesis of cystinosis: effect of CTNS mutations on the transport activity and subcellular localization of cystinosin. Hum Mol Genet 2004 13:1361-1371.

112. Kalatzis V, Cherqui S, Antignac C, Gasnier B: Cystinosin, the protein defective in cystinosis, is a $\mathrm{H}(+)$-driven lysosomal cystine transporter. EMBO J 2001, 20:5940-5949.

113. Sagne C, Agulhon C, Ravassard P, Darmon M, Hamon M, El MS, et al: Identification and characterization of a lysosomal transporter for small neutral amino acids. Proc Natl Acad Sci USA 2001, 98:7206-7211.

114. Saftig P, Klumperman J: Lysosomal biogenesis and lysosomal membrane proteins: trafficking meets function. Nature Reviews 2009, 10:623-635.

115. Ruivo R, Anne C, Sagne C, Gasnier B: Molecular and cellular basis of lysosomal transmembrane protein dysfunction. Biochim Biophys Acta 2009, 1793:636-649.

116. Ballabio A, Gieselmann V: Lysosomal disorders: from storage to cellular damage. Biochim Biophys Acta 2009, 1793:684-696.

117. Klein D, Bussow H, Fewou SN, Gieselmann V: Exocytosis of storage material in a lysosomal disorder. Biochem Biophys Res Commun 2005 327:663-667.

118. Callahan JW, Bagshaw RD, Mahuran DJ: The integral membrane of lysosomes: its proteins and their roles in disease. J Proteomics 2009, 72:23-33.

119. Bagshaw RD, Mahuran DJ, Callahan JW: Lysosomal membrane proteomics and biogenesis of lysosomes. Mol Neurobiol 2005, 32:27-41.

120. Klionsky DJ, Abeliovich H, Agostinis P, Agrawal DK, Aliev G, Askew DS, et al: Guidelines for the use and interpretation of assays for monitoring autophagy in higher eukaryotes. Autophagy 2008, 4:151-175.
121. Park YE, Hayashi YK, Bonne G, Arimura T, Noguchi S, Nonaka I, et al: Autophagic degradation of nuclear components in mammalian cells. Autophagy 2009, 5:795-804.

122. Kraft C, Deplazes A, Sohrmann M, Peter M: Mature ribosomes are selectively degraded upon starvation by an autophagy pathway requiring the Ubp3p/Bre5p ubiquitin protease. Nat Cell Biol 2008, 10:602-610.

123. Tasdemir E, Maiuri MC, Tajeddine N, Vitale I, Criollo A, Vicencio JM, et al: Cell cycle-dependent induction of autophagy, mitophagy and reticulophagy. Cell Cycle 2007, 6:2263-2267.

124. Dengjel J, Kristensen AR, Andersen JS: Ordered bulk degradation via autophagy. Autophagy 2008, 4:1057-1059.

125. Tolkovsky AM: Mitophagy. Biochem Biophys Acta 2009, 1793:1508-1515.

126. Sakai Y, Oku M, Klei van der IJ, Kiel JA: Pexophagy: autophagic degradation of peroxisomes. Biochem Biophys Acta 2006, 1763:1767-1775.

127. Cuervo AM, Stefanis L, Fredenburg R, Lansbury PT, Sulzer D: Impaired degradation of mutant alpha-synuclein by chaperone-mediated autophagy. Science 2004, 305:1292-1295.

128. Qiao L, Zhang J: Inhibition of lysosomal functions reduces proteasomal activity. Neurosci Lett 2009, 456:15-19.

129. Nijssen PC, Brusse E, Leyten AC, Martin JJ, Teepen JL, Roos RA: Autosomal dominant adult neuronal ceroid lipofuscinosis: parkinsonism due to both striatal and nigral dysfunction. Mov Disord 2002, 17:482-487.

130. Zimran A, Neudorfer O, Elstein D: The glucocerebrosidase gene and Parkinson's disease in Ashkenazi Jews. N Engl J Med 2005, 352:728-731.

131. Ramirez A, Heimbach A, Grundemann J, Stiller B, Hampshire D, Cid LP, et al: Hereditary parkinsonism with dementia is caused by mutations in ATP13A2, encoding a lysosomal type 5 P-type ATPase. Nat Genet 2006, 38:1184-1191.

132. Sidransky E, Nalls MA, Aasly JO, haron-Peretz J, Annesi G, Barbosa ER, et al: Multicenter analysis of glucocerebrosidase mutations in Parkinson's disease. N Engl J Med 2009, 361:1651-1661.

133. Goker-Alpan O, Giasson Bl, Eblan MJ, Nguyen J, Hurtig HI, Lee VM, et al: Glucocerebrosidase mutations are an important risk factor for Lewy body disorders. Neurology 2006.

134. Wong K, Sidransky E, Verma A, Mixon T, Sandberg GD, Wakefield LK, et al: Neuropathology provides clues to the pathophysiology of Gaucher disease. Mol Genet Metab 2004, 82:192-207.

135. Saito Y, Suzuki K, Hulette CM, Murayama S: Aberrant phosphorylation of alpha-synuclein in human Niemann-Pick type C1 disease. J Neuropathol Exp Neurol 2004, 63:323-328.

136. Suzuki K, Iseki E, Togo T, Yamaguchi A, Katsuse O, Katsuyama $K$, et al: Neuronal and glial accumulation of alpha- and beta-synucleins in human lipidoses. Acta Neuropathol (Berl) 2007, 114:481-489.

137. Lavrov AY, Ilyna ES, Zakharova EY, Boukina AM, Tishkanina SV: The first three Russian cases of classical, late-infantile, neuronal ceroid lipofuscinosis. Eur J Paediatr Neurol 2002, 6:161-164.

138. Siintola E, Partanen S, Stromme P, Haapanen A, Haltia M, Maehlen J, et al: Cathepsin $D$ deficiency underlies congenital human neuronal ceroidlipofuscinosis. Brain 2006, 129:1438-1445.

139. Steinfeld R, Reinhardt K, Schreiber K, Hillebrand M, Kraetzner R, Bruck W, et al: Cathepsin D deficiency is associated with a human neurodegenerative disorder. Am J Hum Genet 2006, 78:988-998.

140. Cullen V, Lindfors M, Ng J, Paetau A, Swinton E, Kolodziej P, et al: Cathepsin $D$ expression level affects alpha-synuclein processing, aggregation, and toxicity in vivo. Mol Brain 2009, 2:5.

141. Luiro K, Kopra O, Blom T, Gentile M, Mitchison HM, Hovatta I, et al: Batten disease (JNCL) is linked to disturbances in mitochondrial, cytoskeletal, and synaptic compartments. J Neurosci Res 2006, 84:1124-1138.

142. Jolly RD, Brown S, Das AM, Walkley SU: Mitochondrial dysfunction in the neuronal ceroid-lipofuscinoses (Batten disease). Neurochem Int 2002, 40:565-571.

143. Anglade P, Vyas S, Javoy-Agid F, Herrero MT, Michel PP, Marquez J, et al: Apoptosis and autophagy in nigral neurons of patients with Parkinson's disease. Histol Histopathol 1997, 12:25-31.

144. Nixon RA, Wegiel J, Kumar A, Yu WH, Peterhoff C, Cataldo A, et al: Extensive involvement of autophagy in Alzheimer disease: an immunoelectron microscopy study. J Neuropathol Exp Neurol 2005, 64:113-122. 
145. Yu WH, Cuervo AM, Kumar A, Peterhoff CM, Schmidt SD, Lee JH, et al: Macroautophagy-a novel Beta-amyloid peptide-generating pathway activated in Alzheimer's disease. J Cell Biol 2005, 171:87-98.

146. Yu WH, Dorado B, Figueroa HY, Wang L, Planel E, Cookson MR, et al: Metabolic activity determines efficacy of macroautophagic clearance of pathological oligomeric alpha-synuclein. Am J Pathol 2009, 175:736-747.

147. Butler D, Nixon RA, Bahr BA: Potential compensatory responses through autophagic/lysosomal pathways in neurodegenerative diseases. Autophagy 2006, 2:234-237.

148. Butler D, Brown QB, Chin DJ, Batey L, Karim S, Mutneja MS, et al: Cellular responses to protein accumulation involve autophagy and lysosomal enzyme activation. Rejuvenation Res 2005, 8:227-237.

149. Cataldo AM, Barnett JL, Pieroni C, Nixon RA: Increased neuronal endocytosis and protease delivery to early endosomes in sporadic Alzheimer's disease: neuropathologic evidence for a mechanism of increased beta-amyloidogenesis. J Neurosci 1997, 17:6142-6151.

150. Chu Y, Dodiya H, Aebischer P, Olanow CW, Kordower JH: Alterations in lysosomal and proteasomal markers in Parkinson's disease: Relationship to alpha-synuclein inclusions. Neurobiol Dis 2009, 35:385-398.

151. Stefanis L, Larsen KE, Rideout HJ, Sulzer D, Greene LA: Expression of A53T mutant but not wild-type alpha-synuclein in PC12 cells induces alterations of the ubiquitin-dependent degradation system, loss of dopamine release, and autophagic cell death. J Neurosci 2001, 21:9549-9560

152. Martinez-Vicente M, Talloczy Z, Kaushik S, Massey AC, Mazzulli J Mosharov EV, et al: Dopamine-modified alpha-synuclein blocks chaperone-mediated autophagy. J Clin Invest 2008, 118:777-788.

153. Erickson AH, Blobel G: Carboxyl-terminal proteolytic processing during biosynthesis of the lysosomal enzymes beta-glucuronidase and cathepsin D. Biochemistry 1983, 22:5201-5205.

154. Zubenko GS, Park FJ, Jones EW: Mutations in PEP4 locus of Saccharomyces cerevisiae block final step in maturation of two vacuolar hydrolases. Proc Natl Acad Sci USA 1983, 80:510-514.

155. Woolford CA, Daniels LB, Park FJ, Jones EW, Van Arsdell JN, Innis MA: The PEP4 gene encodes an aspartyl protease implicated in the posttranslational regulation of Saccharomyces cerevisiae vacuolar hydrolases. Mol Cell Biol 1986, 6:2500-2510.

156. Woolford CA, Noble JA, Garman JD, Tam MF, Innis MA, Jones EW: Phenotypic analysis of proteinase A mutants. Implications for autoactivation and the maturation pathway of the vacuolar hydrolases of Saccharomyces cerevisiae. J Biol Chem 1993, 268:8990-8998.

157. Marques M, Mojzita D, Amorim MA, Almeida T, Hohmann S, MoradasFerreira $P$, et al: The Pep4p vacuolar proteinase contributes to the turnover of oxidized proteins but PEP4 overexpression is not sufficient to increase chronological lifespan in Saccharomyces cerevisiae. Microbiology 2006, 152:3595-3605.

158. Koike M, Shibata M, Waguri S, Yoshimura K, Tanida I, Kominami E, et al: Participation of autophagy in storage of lysosomes in neurons from mouse models of neuronal ceroid-lipofuscinoses (Batten disease). Am J Pathol 2005, 167:1713-1728.

159. Koike M, Shibata M, Ohsawa Y, Nakanishi H, Koga T, Kametaka S, et al: Involvement of two different cell death pathways in retinal atrophy of cathepsin D-deficient mice. Mol Cell Neurosci 2003, 22:146-161.

160. Nakanishi H, Zhang J, Koike M, Nishioku T, Okamoto $Y$, Kominami E, et al: Involvement of nitric oxide released from microglia-macrophages in pathological changes of cathepsin D-deficient mice. J Neurosci 2001, 21:7526-7533

161. Koike M, Nakanishi H, Saftig P, Ezaki J, Isahara K, Ohsawa Y, et al: Cathepsin $D$ deficiency induces lysosomal storage with ceroid lipofuscin in mouse CNS neurons. J Neurosci 2000, 20:6898-6906.

162. Saftig P, Hetman M, Schmahl W, Weber K, Heine L, Mossmann H, et al: Mice deficient for the lysosomal proteinase cathepsin $D$ exhibit progressive atrophy of the intestinal mucosa and profound destruction of lymphoid cells. EMBO J 1995, 14:3599-3608.

163. Qiao L, Hamamichi S, Caldwell KA, Caldwell GA, Yacoubian TA, Wilson S, et al: Lysosomal enzyme cathepsin D protects against alpha-synuclein aggregation and toxicity. Mol Brain 2008, 1:17.

164. Hasegawa M, Fujiwara H, Nonaka T, Wakabayashi K, Takahashi H, Lee VM, et al: Phosphorylated alpha-synuclein is ubiquitinated in alphasynucleinopathy lesions. J Biol Chem 2002, 277:49071-49076.
165. Fujiwara $H$, Hasegawa M, Dohmae N, Kawashima A, Masliah E, Goldberg MS, et al: alpha-Synuclein is phosphorylated in synucleinopathy lesions. Nat Cell Biol 2002, 4:160-164.

166. Yang Q, She H, Gearing M, Colla E, Lee M, Shacka JJ, et al: Regulation of neuronal survival factor MEF2D by chaperone-mediated autophagy. Science 2009, 323:124-127.

167. Tang CH, Lee JW, Galvez MG, Robillard L, Mole SE, Chapman HA: Murine cathepsin F deficiency causes neuronal lipofuscinosis and late-onset neurological disease. Mol Cell Biol 2006, 26:2309-2316.

168. Yamamoto A, Cremona ML, Rothman JE: Autophagy-mediated clearance of huntingtin aggregates triggered by the insulin-signaling pathway. $J$ Cell Biol 2006, 172:719-731.

169. Sarkar S, Davies JE, Huang Z, Tunnacliffe A, Rubinsztein DC: Trehalose, a novel mTOR-independent autophagy enhancer, accelerates the clearance of mutant huntingtin and alpha-synuclein. J Biol Chem 2007, 282:5641-5652.

170. Berger Z, Ravikumar B, Menzies FM, Oroz LG, Underwood BR, Pangalos MN, et al: Rapamycin alleviates toxicity of different aggregate-prone proteins. Hum Mol Genet 2006, 15:433-442.

171. Sarkar S, Floto RA, Berger Z, Imarisio S, Cordenier A, Pasco M, et al: Lithium induces autophagy by inhibiting inositol monophosphatase. J Cell Biol 2005, 170:1101-1111.

172. Sarkar S, Rubinsztein DC: Inositol and IP3 Levels Regulate Autophagy: Biology and Therapeutic Speculations. Autophagy 2006, 2:132-134.

173. Menzies FM, Ravikumar B, Rubinsztein DC: Protective roles for induction of autophagy in multiple proteinopathies. Autophagy 2006, 2:224-225.

174. Ravikumar B, Vacher C, Berger Z, Davies JE, Luo S, Oroz LG, et al: Inhibition of mTOR induces autophagy and reduces toxicity of polyglutamine expansions in fly and mouse models of Huntington disease. Nat Genet 2004, 36:585-595.

175. Sarkar S, Krishna G, Imarisio S, Saiki S, O'Kane CJ, Rubinsztein DC: A rational mechanism for combination treatment of Huntington's disease using lithium and rapamycin. Hum Mol Genet 2008, 17:170-178.

176. Hossain S, Alim A, Takeda K, Kaji H, Shinoda T, Ueda K: Limited proteolysis of NACP/alpha-synuclein. J Alzheimers Dis 2001, 3:577-584.

177. Hodara R, Norris EH, Giasson BI, Mishizen-Eberz AJ, Lynch DR, Lee VM, et al: Functional consequences of alpha-synuclein tyrosine nitration: diminished binding to lipid vesicles and increased fibril formation. $J$ Biol Chem 2004, 279:47746-47753.

178. Sevlever D, Jiang P, Yen SH: Cathepsin D is the main lysosomal enzyme involved in the degradation of alpha-synuclein and generation of its carboxy-terminally truncated species. Biochemistry 2008, 47:9678-9687.

179. Takahashi T, Yamashita H, Nakamura T, Nagano Y, Nakamura S: Tyrosine 125 of alpha-synuclein plays a critical role for dimerization following nitrative stress. Brain Res 2002, 938:73-80.

180. Duda JE, Giasson Bl, Chen Q, Gur TL, Hurtig HI, Stern MB, et al: Widespread nitration of pathological inclusions in neurodegenerative synucleinopathies. Am J Pathol 2000, 157:1439-1445.

181. Giasson BI, Duda JE, Murray IV, Chen Q, Souza JM, Hurtig HI, et al: Oxidative damage linked to neurodegeneration by selective alpha-synuclein nitration in synucleinopathy lesions. Science 2000, 290:985-989.

182. McLean PJ, Kawamata H, Hyman BT: Alpha-synuclein-enhanced green fluorescent protein fusion proteins form proteasome sensitive inclusions in primary neurons. Neuroscience 2001, 104:901-912.

183. Cooper AA, Gitler AD, Cashikar A, Haynes CM, Hill KJ, Bhullar B, et al: Alphasynuclein blocks ER-Golgi traffic and Rab1 rescues neuron loss in Parkinson's models. Science 2006, 313:324-328.

184. St Martin JL, Klucken J, Outeiro TF, Nguyen P, Keller-McGandy C, CantutiCastelvetri l, et al: Dopaminergic neuron loss and up-regulation of chaperone protein mRNA induced by targeted over-expression of alphasynuclein in mouse substantia nigra. J Neurochem 2007, 100:1449-1457.

185. Gitler AD, Chesi A, Geddie ML, Strathearn KE, Hamamichi S, Hill KJ, et al: Alpha-synuclein is part of a diverse and highly conserved interaction network that includes PARK9 and manganese toxicity. Nat Genet 2009, 41:308-315.

doi:10.1186/1750-1326-5-14

Cite this article as: Schneider and Zhang: Lysosomal function in macromolecular homeostasis and bioenergetics in Parkinson's disease. Molecular Neurodegeneration 2010 5:14. 